\title{
Voter Registration: A Restriction on the Fundamental Right to Vote
}

\author{
Deborah S. James
}

Fully thirty-five to forty percent of eligible Americans are not registered to vote, and are therefore unable to cast a ballot on election day. ${ }^{1}$ This Note presents a framework for challenging the pre-election day registration requirement as violative of the fundamental right to cast a ballot on election day ${ }^{2}$ in general purpose elections. ${ }^{3}$

Currently, one state does not require registration, ${ }^{4}$ and three states allow registration on election day. ${ }^{5}$ Critically, in the remaining states, registration may close up to fifty days prior to the election, ${ }^{6}$ preventing voting by eligible persons who realize their interest in a particular election only during the increasing exchange of ideas that accompanies the approach of an election. In addition to the closing date obstacle, many of these states' statutes either mandate restrictive registration practices or allow local registrars wide latitude concerning whether to deputize volunteers, establish satellite sites, hold special registration drives, or extend hours. ${ }^{7}$ As a result

1. Stone, Voter Registration: Context and Results, 17 URB. LAw. 519, 520 (1985).

2. Two members of Congress are currently drafting bills that would mandate election day registration in federal elections, to be introduced to the 100th Cong., 1st Sess. (1987). Telephone interviews with Candy Nelson, Congressional Fellow to Sen. Alan Cranston (May 28, 1987) and Julian Epstein, Legislative Director to Rep. John Conyers (June 1, 1987). National legislation would remove the need for case by case review of state registration practices in court. This Note maintains, however, that there is a constitutional right to cast a ballot on election day that can be vindicated in court without need for legislative directive.

3. This Note applies to general elections for officials with broad governmental powers, such as state and federal senators and representatives. In interim elections and special purpose elections, in contrast, the Court has identified justifications for limiting the eligible electorate beyond what would be permissible in general elections. Regarding interim elections, the Court has upheld an electoral scheme in which only persons registered in the same political party as the official whose position is vacated are eligible to vote. The Court acknowledged compelling state interests particular to interim elections, such as in "ensuring the stability and continuity of the 'legislative balance' until the next general election; protecting the 'electoral mandate' of the previous election; and reducing 'inter-partisan political campaigns to once every four years." " Rodriguez v. Popular Democratic Party, 457 U.S. 1, 4 (1982) (quoting Popular Democratic Party v. Barcelo, Puerto Rico (1981)). Regarding special purpose elections, the Court has permitted a state to limit the eligible electorate to those with a disproportionate stake in the outcome. See Ball v. James, 451 U.S. 355 (1981) (election of directors of entity with primary function to distribute water based on land ownership permissibly limited to landowners).

4. N.D. CENT. CODE \& 16.1-02 (1981).

5. Mr. Rkv. STAT. $\Lambda$ NN. tit. $21-\Lambda$, § 122(4) (West Supp. 1986); Minn. STat. ANN. $\S 201.16(3)$ (West Supp. 1987); Wis. SrAT. ANN. \& 6.29 (West 1986).

6. See Lfiacius: of Women Votrers Education Fund, Pub. No. 522, Easy Does It: Registrattion and Arsentre: Voting Procedures by State (1984) (chart).

7. See, e.g., Al.A. ConE $\S 17-4-158$ (Supp. 1986) (discretionary appointment of deputy regis- 
of this discretion, registration practices of some states, such as Virginia, vary widely from county to county. ${ }^{8}$

Twenty-one states and the District of Columbia do allow all eligible persons to register by mail. ${ }^{9}$ Moreover, some states have recently increased voter registration outreach efforts, in certain cases spurred by legal challenges to specific restrictive registration practices. ${ }^{10}$ These actions, while

trars); Fl.A. S'ra'. ANN. § 98.271(1), (2) (West Supp. 1984) (same); Ga. CodE ANN. § 21-3-120(d) (Supp. 1986) (same); id. $\S 21-2-218(f)$ (registration only in public places, preventing door-to-door registration); InAHO CODF: $\$ \S 34-209$ (1) (1981) (discretionary appointment of deputy registrars); Iowa Codr $\Lambda$ NN. \$ 48.4 (West Supp. 1986-1987) (same); LA. Rev. STat. ANN. § 18:59I (West Supp. 1986) (temporary deputy registrars prohibited); $i d$. \& 18:133 (West 1979) (discretionary satel-

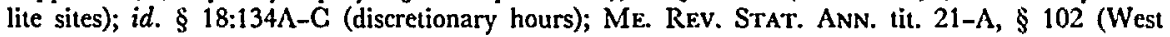
Supp. 1986) (discretionary appointment of deputy registrars); Mn. ElEc. CoDE ANN. Art. 33 \& 3-10(a) (1986) (same); id. § 3-2(a), (c) (discretionary sites and hours); MAss. ANN. LAws ch. 51, $\$ \S$ 22, $22 \Lambda$ (Michie/Law. Co-op. 1978) (discretonary appointment of deputy registrars); MiCH. CoMP. LAws ANN. \$ 168.498 (West 1967) (discretionary sites and hours); Miss. Code ANN. § 23-5-29 (Supp. 1986) (discretionary satellite sites); id. \$ 21-11-1, -3 (dual registration required in some municipalities) ; Mo. ANN. Srar. \$ 115.143(2) (Vernon Supp. 1987) (discretionary appointment of deputy registrars); $i d$. $\$ 115.143$ (5) (discretionary satellite sites); NEB. REV. STAT. $\$ 32-208$ (1984) (discretionary appointment of deputy registrars); id. § 32-216(3), (4) \& 32-216.01 (limited sites and discretionary hours); Nk.v. Rrv. SrAT. § 293.505(2) (1986) (discretionary appointment of deputy registrars); N.J. SIAT. ANN. § 19:31-2 (West Supp. 1986) (same); OR. Rev. Stat. 246.250(1) (1985) (same); PA. SrAT. ANN. tit. 25, § 951-5 (Purdon 1963) (same); id. \$ 951-16(a) (discretionary hours); S.C. CoDE ANN. \$ 7-5-20 (Law. Co-op. Supp. 1986) (discretionary appointment of deputy registrars); id. § 7-5-140 (discretionary hours); TENN. CODE ANN. § 2-12-201 (1985) (volunteers not eligible as deputy registrars); id. § 2-2-111 (discretionary satellite sites); VA. ConE ANN. § 24.1-45.2 (Supp. 1986) (discretionary registration in state agencies); id. $\$ 24.1-46$ (registrar prohibited from actively soliciting registrants); id. \$ 24.1-49 (1985) (discretionary hours).

8. See J. Goldberg \& R. Taylor, Voter Registration Practices in Virginia-the Crazy Quilt (July 1984) (unpublished $\Lambda$ CLU Public Policy Report) (photo. reprint on file with author); R. Slattery, Virginia's Voter Registration Laws: $\Lambda$ Comparative $\Lambda$ nalysis (Nov. 1983) (unpublished manuscript) (photo. reprint on file with author).

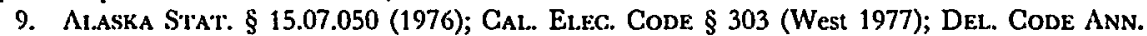
tit. 15, § 2012 (1982); D.C. Code ANN. \$ 1-1311(c) (1984); HAw. Rev. Stat. \$ 11-16 (1976); Iowa Cone ANN. § 48.3 (West 1982); Kan. Stat. ANN. § 25-2309 (1981); Ky. Rev. Stat. AnN. § 116.045 (Michie/Bobbs-Merrill 1982); Mo. El.ec. Code AnN. \$ 3-1(c) (1986); MinN. Stat. AnN. $\S 201.061$ (West Supp. 1987); Monr. Conf ANN. § 13-2-203 (1983); Neb. Rev. Stat. § 32-221 (R.S. Supp. 1986); N.J. STAT. ANN. § 19.31-6.3 (West Supp. 1986); N.Y. El.EC. Law $\S 5-210(1)$ (McKinney 1978); Ohio Rev. Code ANN. $\$ 3503.11$ (Anderson 1972); OR. Rev. STat. $\$ 247.012$ (1983); PA. STAT: ANN. tit. 25, §§ 623-19.1(a), 951-17.1(a) (Purdon Supp. 1986); TENN. CodE ANN. § 2-2-115 (1985); Trx. El.k.. CoDE. ANN. $\S 13.002$ (Vernon 1986); UTAH CodE ANN. § 20-2-7 (1984); W. VA. Codf § 3-2-41 (1987); Wis. Stat. ANN. § 6.30(4) (West 1986).

10. In one line of cases plaintiffs successfully asserted the right of free speech in a public forum, enabling already deputized registrars to enter welfare and unemployment offices for the purpose of signing up registrants. See, e.g., Project Vote v. Ohio Bureau of Employment Servs., 578 F. Supp. 7 (S.D. Ohio 1982). Another line of cases found plaintiffs to have a valid freedom of association claim when a registrar appointed deputies only from certain organizations but not from the plaintiffs organization. See, e.g., Project Vote v. Distefano, No. 84-03228 (1st Cir. June 27, 1984) (temporary restraining order). In such cases courts have ordered registrars to establish an objective, non-partisan basis for selecting deputies. Other cases resulted in settlements in which states agreed to take steps to facilitate registration or to conduct a study of outreach alternatives. The state of Michgan agreed to a settlement in August 1985 prohibiting discrimination in the appointment of deputy registrars. Louisiana agreed in a settlement in 1986 to conduct a study of outreach methods in districts with the greatest disparity between black and white registration rates. $\Lambda$ settlement was reached in Georgia in 1986 under which each county was to submit plans for registration efforts. See The Human Serve Campaign, Litigating the Right To Register and To Cast a Ballot: $A$ Summary of Current Cases and 
encouraging, have failed to resolve the two key questions addressed in this Note: First, under what circumstances is any pre-election day registration requirement constitutionally permissible; and second, when pre-election day registration is allowable, is the state obliged to minimize the burden the registration obstacle imposes on the individual?

This Note argues that registration is a per se restriction of the right to vote. First, it demonstrates that the right to cast a ballot in general purpose elections is fundamental. Second, it argues that the imposition of any registration prerequisite constitutes "any restriction" on this fundamental right. Third, applying strict scrutiny analysis, the Note examines possible state interests that might justify a voter registration requirement. Upon finding fraud prevention to be the only possible state interest reaching "compelling" stature, it examines the extent to which states actually use registration as a means to prevent fraud. The Note then proposes a method for applying least restrictive means analysis in the registration context.

\section{The Substantive Right To Vote in the Equal Protection Glause}

The "fundamental rights" tier of the equal protection clause calls for application of strict scrutiny when a restriction is placed on the exercise of a fundamental right. ${ }^{11}$ The restriction, regardless of the basis of the classification, will be upheld only when it is the least restrictive means of furthering a compelling state interest. ${ }^{12}$

Approaches (Ocl. 1986) (photo. reprint on file with author). For further discussion of facilitative state practices, see infra notes 121-25 and accompanying text.

11. Strict scrutiny is also applied to discrimination on the basis of "suspect classifications" such as race, see, e.g., Loving v. Virginia, 388 U.S. 1 (1967); McLaughlin v. Florida, 379 U.S. 184 (1964), national ancestry, see, e.g., Korematsu v. United States, 323 U.S. 214 (1944), and alienage, see, e.g., Sei Fujii v. State, 38 Cal. 2d 718, 242 P.2d 617 (1952). With suspect classifications, in contrast to fundamental rights, it is the nature of the classification, not the nature of the activity, that triggers strict scrutiny. To bring suit claiming discrimination against a suspect class when the legislation is facially neutral, plaintiff must establish that the purpose of the legislation was at least partially motivated by an illicit classification, such as race. Village of Arlington Heights v. Metropolitan Hous. Dev. Corp., 429 U.S. 252 (1977); Washington v. Davis, 426 U.S. 229 (1976).

When suspect classifications and fundamental rights are not involved, traditional equal protection analysis requires that a state show merely a rational relationship between the classification and a legitimate state interest. See, e.g., Vance v. Bradley, 440 U.S. 93, 97, 111 (1979) (mandatory retirement); Lindsey v. Normet, 405 U.S. 56 (1972) (decent shelter). For a study of the history and current status of the rational basis test, see Bennett, "Mere" Rationality in Constitutional Law: Judicial Revolution and Democratic Theory, 67 CAl.IF. L. Rev. 1049 (1979).

12. Roberts v. United States Jaycees, 468 U.S. 609, 623 (1984) (least restrictive means of furthering compelling state interest required when freedom of association infringed); Dunn v. Blumstein, 405 U.S. 330,337 (1972) (durational residency requirement as prerequisite to voter eligibility not necessary to promote compelling state interest); Shapiro v. Thompson, 394 U.S. 618, 634 (1968) ("[A]ny classification which serves to penalize the exercise of that right [to travel], unless shown to be necessary to promote a compelling governmental interest, is unconstitutional."); see also Katzenbach v. Morgan, 384 U.S. 641, 655 n.15 (1966) (narrowly tailored means required when fundamental rights 


\section{A. The Fundamental Right to Cast a Ballot on Election Day}

Courts should deem the individual's right ${ }^{13}$ to cast a ballot free from pre-election day encumbrances to be fundamental. Voting clearly constitutes some form of a fundamental right ${ }^{14}$ that states must respect despite their power under the Constitution to set voter qualifications and election regulations. ${ }^{15}$ The ambiguity is whether the individual's "right to vote" is

and liberties threatened); Carrington v. Rash, 380 U.S. 89, 96 (1965) (unconstitutionally over- and under-inclusive to disenfranchise military as means of insuring that only residents vote); Shelton v. Tucker, 364 U.S. 479, 488 (1960) (requiring narrowly tailored means).

13. This Note discusses the individual's right to cast a ballot, and therefore, does not concern the more tenuous constitutional status of group rights in the voting context. The Supreme Court has drawn a distinction between individual and group rights to vote:

$[T]$ here is a fundamental distinction between state action that inhibits an individual's right to vote and state action that affects the political strength of various groups that compete for leadership in a democratically governed community. That distinction divides so-called vote dilution practices into two different categories "governed by entirely different constitutional considerations."

City of Mobile v. Bolden, 446 U.S. 55, 83 (1980) (Stevens, J., concurring) (quoting Wright v. Rockefeller, 376 U.S. 52, 58 (1964) (Harlan, J., concurring)); see also Shelley v. Kraemer, 334 U.S. 1, 22 (1948) ("The rights created by the first section of the Fourteenth Amendment are, by its terms, guaranteed to the individual.") (emphasis added). Individual and group rights in the voting context could be viewed as intertwined. See Fiss, Groups and the Equal Protection Clause, 5 PHIL. \& PuB. AFF. 107, 148-56 (1976) (suggesting broader interpretation of constitutional rights). Since the theory developed in this Note rests on the individual's fundamental right, it need not reach the question of the validity of the individual/groups rights distinction.

$\Lambda$ claim of disparate registration rates between minority and white groups could conceivably be brought under section two of the Voting Rights Act, Pub. L. No. 89-110, 79 Stat. 437 (1965) (codified as amended at 42 U.S.C. $\$ 1973$ (1982)); see Note, Eradicating Racial Discrimination in Voter Registration: Rights and Remedies under the Voting Rights Act Amendments of 1982, 52 FORDHAM L. Rrv. 93 (1983). See generally Parker, The "Results" Test of Section 2 of the Voting Rights Act: Abandoning the Intent Standard, 69 VA. L. Rrv. 715 (1983).

14. See, e.g., Wesberry v. Sanders, 376 U.S. 1, 17 (1964) ("No right is more precious in a free country than that of having a voice in the election of those who make the laws under which, as good citizens, we must live. Other rights, even the most basic, are illusory if the right to vote is undermined."); Yick Wo v. Hopkins, 118 U.S. 356, 370 (1886) (Voting is "a fundamental political right, because [it is] preservative of all rights.").

15. States are granted the power under the Constitution to establish voter qualifications. U.S. Const: art. I, \$ 2, cl. 1. States are also authorized to set "[t] the Times, Places and Manner of holding Elections for Senators and Representatives." U.S. Consr. art. I, § 4, cl. 1; see id. amend. XVII. States could conceivably choose to fill certain public offices by election or appointment. See Rodriguez v. Popular Democratic Party, 457 U.S. 1, 11 (1982). However, this does not diminish the applicability of strict scrutiny once the franchise is granted. Kramer v. Union Free School Dist. No. 15, 395 U.S. 621, 628-29 (1969). After granting the franchise, states may not exercise their right to set qualifications and regulations in a manner that conflicts with other provisions of the Constitution, including the strict scrutiny accorded fundamental rights under the equal protection clause of the Fourteenth $\Lambda$ mendment. The Supreme Court has stated:

Obviously we must reject the notion that Art. II, $\S 1$, gives the States power to impose burdens on the right to vote, where such burdens are expressly prohibited in other consitutional provisions. We therefore hold that no State can pass a law regulating elections that violates the Fourteenth Amendment's command that "No State shall ... deny to any person... the equal protection of the laws."

Williams v. Rhodes, 393 U.S. 23, 29 (1968); see also Rodriguez v. Popular Democratic Party, 457 U.S. $1,10(1982)$ (" $\Lambda]$ citizen has a constitutionally protected right to participate in elections on an equal basis with other citizens in the jurisdiction.' " (quoting Dunn v. Blumstein, 405 U.S. 330, 336 (1972))); Moore v. Ogilvie, 394 U.S. 814, 818 (1969) ("/ll procedures used by a State as an integral part of the election process must pass muster against the charges of discrimination or of abridgement 
substantive, providing an entitlement to all qualified voters to be free from obstacles to casting a ballot, or merely a right of equal access. The conclusion that the right should be deemed substantive is the logical convergence of three strands of American jurisprudence: first, the substantive manner in which fundamental rights have been interpreted in the equal protection clause; second, the applicability of heightened judicial scrutiny to legislation concerning "process defects;" and third, the special treatment in practice accorded individual voting rights under the Constitution, especially since Reynolds v. Sims. ${ }^{16}$

\section{The Fundamental Rights Doctrine}

The notion that there are rights implicit in the equal protection clause of the Constitution only emerged in 1942 with Skinner v. Oklahoma ex rel. Williamson. ${ }^{17}$ Since then the Supreme Court has declared a number of rights to be fundamental under the equal protection clause, ${ }^{18}$ and the list of rights courts consider fundamental is constantly evolving. ${ }^{19}$

Fundamental rights analysis looks to the nature of the activity, not the basis of the classification. ${ }^{20}$ Strict scrutiny is triggered by an infringement on a substantive entitlement, implicit or explicit in the Constitution. ${ }^{21}$ The

of the right to vote.").

16. 377 U.S. 533 (1964).

17. 316 U.S. 535 (1942); see Developments in the Law: Equal Protection, 82 Harv. L. Rev. 1065,1131 (1969). Any pre-Skinner framing of the right to vote as merely one of equal access, e.g., Nixon v. Herndon, 273 U.S. 536-37 (1927); United States v. Cruishank, 92 U.S. 542, 555-56 (1875), does not take into account current notions of fundamental rights.

18. E.g., Shapiro v. Thompson, 394 U.S. 618, 630 (1969) (right to travel); NAACP v. Button, 371 U.S. 415, 430-31 (1963) (rights of expression and association); Bates v. Little Rock, 361 U.S. $516,523(1960)$ (freedom of association); Griffin v. Illinois, 351 U.S. 12, 16 (1956) (criminal appeal rights).

19. See Harper v. Virginia Bd. of Elections, 383 U.S. 663, 669 (1966) (There is no "fixed catalogue of what was at a given time deemed to be the limits of fundamental rights.").

20. Shapiro v. Thompson, 394 U.S. 618, 660 (1969) (Harlan, J., dissenting) ("[A] statutory classification is subject to the 'compelling interest' test if the result of the classification may be to affect a 'fundamental right,' regardless of the basis of the classification."); United States v. Cohen, 733 F.2d 128,133 (D.C. Cir. 1984) ("[T]he focus, for purposes of determining whether a 'fundamental interest' is involved, is not upon the punishment or other imposition to which the complaining party has been subjected, but rather upon the activity [at issue] . . . ."); Perry, Modern Equal Protection: A Conceptualization and Appraisal, 79 Col.uM. L. REv. 1023, 1077 (1979); Developments in the Law: Equal Protection, supra note 17, at 1180 n.78, 1181 n.82 (fundamental rights strand of equal protection analysis applicable regardless of how "equally" activity is invaded).

21. The Supreme Court has suggested that the right to vote is grounded in various provisions of the Constitution. Wesberry v. Sanders, 376 U.S. 1, 17 (1963) (right to vote in federal elections grounded in Art. I, $\S 2$ of Constitution); accord Lubin v. Panish, 415 U.S. 709, 721 n.* (1973) (Ninth and Seventeeth Amendments); Storer v. Brown, 415 U.S. 724, 756 (1973) (First Amendment); Harper, 383 U.S. at 664 (same). Still, an explicit constitutional reference is not necessary in order to apply substantive fundamental rights analysis. Shapiro v. Thompson, 394 U.S. 618, 630 (1968) ("We have no occasion to ascribe the source of this right to travel interstate to a particular constitutional provision."). Similarly, in Skinner, 316 U.S. at 541, the Supreme Court accorded the right to procreate fundamental right status under the equal protection clause although it had previously, in Buck v. Bell, 274 U.S. 200, 208 (1927), refused to recognize an explicit constitutional guarantee of that right. 
structure of fundamental rights equal protection analysis does require that a "classification" impose a restriction on the fundamental right. The registration requirement produces such a classification; the class of persons harmed by the registration requirement consists of those who on election day would like to cast a ballot and are otherwise eligible but are blocked from doing so for not having registered. ${ }^{22}$ However, a restriction on a fundamental right need not disadvantage one definable group relative to another ${ }^{23}$ Moreover, the purpose of the classification is not material; it is not necessary to demonstrate an intent to obstruct access of exactly those who do not register. ${ }^{24}$

\section{Process Defects}

Courts have recognized the importance of applying heightened scrutiny to legislation that impedes the democratic political processes necessary to challenge the harmful legislation. In its famous footnote in Carolene Products, the Court said: "[L]egislation which restricts those political processes which can ordinarily be expected to bring about repeal of undesirable legislation, is to be subjected to more exacting judicial scrutiny under the general prohibitions of the Fourteenth Amendment than are most other types of legislation." 25

22. The pre-election day registration requirement erects two sorts of barriers: first, by requiring an individual to expend additional time and effort before being eligible to vote, and second, by imposing an absolute barrier before persons who become aware of their preference for a specific candidate only after the registration deadline has passed.

23. Developments in the Law: Equal Protection, supra note 17, at $1180 \mathrm{n} .78$ ("equal protection may confer protection of substantive rights no matter how 'equally' the right is invaded"); see also Bullock v. Carter, 405 U.S. 134, 144 (1972) (injury found despite inability to pinpoint exact voters harmed); Harper, 383 U.S. at 668 (implying that poll tax burdened all voters, not just those unable to pay).

It has been argued that the fundamental rights strand of equal protection analysis is not properly an equal protection issue since it grants substantive, not just relative rights, and that matters such as voting should instead be deemed quasi-fundamental rights, enforced independently of the equal protection clause. See Perry, supra note 20, at 1077, 1081. Although this alternative approach could be developed, it is not necessary to step out of equal protection analysis to find a substantive right to vote because the Supreme Court has already established the framework for substantive fundamental rights analysis within the equal protection clause.

24. See, e.g., Zobel v. Williams, 457 U.S. 55, 66 (1982) (Brennan, J. concurring) (heightened scrutiny applicable to burden on right to travel without examining legislative intent); City of Mobile v. Bolden, 446 U.S. 55, 113 (1980) (Marshall, J., dissenting) (strict scrutiny applicable to fundamental rights "regardless of whether the infringement was intentional"); J. ELY, DEMOCRACY AND DisTRUSr 45 (1980) (motive to discriminate not relevant in fundamental rights analysis); Note, Rethinking Selective Enforcement in the First Amendment Context, 84 Col.uM. L. REv. 144, 156 (1984) (same).

The intent standard enunciated in Village of Arlington Heights v. Metropolitan Hous. Dev. Corp., 429 U.S. 252, 265 (1977), and Washington v. Davis, 426 U.S. 229, 245 (1976), was developed in and is applicable to the suspect classification strand, not the fundamental rights strand, of equal protection analysis. See supra note 11.

25. United States v. Carolene Prods. Co., 304 U.S. 144, 152 n.4 (dictum); see also L. TRIBE, AMERICAN CONSIIIUTIONAI. LAw § 13-18 (1978) ("[C]ourts should be chary of efforts by government officials to control the very electoral system which is the primary check on their power."); 
Both courts and commentators have recognized that the high importance of voting stems from its centrality to the political process. As the Supreme Court observed over a century ago, voting is "a fundamental political right, because [it is] preservative of all rights." ${ }^{26}$ More recently, in elaborating on the process defect argument, Dean John Hart Ely noted that "unblocking stoppages in the democratic process is what judicial review ought preeminently to be about, and denial of the vote seems the quintessential stoppage." ${ }^{\prime 27}$ Voter registration laws fall squarely within the realm of process defects because elected officials have no incentive to be responsive to persons who are unable to vote. ${ }^{28}$ Legislators have a vested interest in maintaining the status quo-that is, in ensuring that those who voted them into office will continue to be the only voters. ${ }^{29}$

\section{Voting Rights Cases}

The Supreme Court has addressed the nature of the individual's right to vote in the context of voter qualification, reapportionment, and candidate ballot access cases. The claim that the right to vote is just a matter of

Sherry, Selective Judicial Activism in the Equal Protection Context: Democracy, Distrust, and Deconstruction, 73 Gro. L.J. 89, 103-05 (1984) (heightened scrutiny needed in instances where democratic political processes cannot be expected to rectify harm); Developments in the Law: Equal Protection, supra note 17, at 1129 ("Any restriction on a person's ability to participate in the political process must be carefully scrutinized in a society where basic decisions are made and gain acceptability through the political mechanisms of a representative democracy.").

26. Yick Wo v. Hopkins, 118 U.S. 356, 370 (1886); see also Kramer v. Union Free School Dist. No. 15, 395 U.S. 621, 627 (1969) ("IT]he deference usually given to the judgment of legislators does not extend to decisions concerning which resident citizens may participate in the election of legislators and other public officials."); Reynolds v. Sims, 377 U.S. 533, 555 (1964) ("[A]ny restrictions on that right [to vote] strike at the heart of representative government.").

27. J. Eı.Y, supra note 24, at 117.

28. Cf. South Carolina State Highway Dep't v. Barnwell Bros., 303 U.S. 177, 184-85 \& n.2 (1938) (in case involving state regulation of commerce, Court noted that "when the regulation is of such a character that its burden falls principally upon those without the state, legislative action is not likely to be subjected to those political restraints which are normally exerted on legislation where it affects adversely some interests within the state").

29. Application of the Carolene Products process defects doctrine to voter registration does not require an interventionist interpretation of the doctrine's scope. Courts are called on merely to eliminate the state-imposed registration obstacle. See Rendell-Baker v. Kohn, 457 U.S. 830 (1982) (courts may prohibit, but not mandate, government action); Flagg Bros. v. Brooks, 436 U.S. 149 (1978) (no judicial relief to state inaction in contrast to state-imposed obstacle); Brest, State Action and Liberal Theory: A Casenote on Flagg Brothers v. Brooks, 130 U. PA. L. REv. 1296 (1982). Moreover, the court would just be setting in motion a procedural change, not attempting to reconstruct the outcome that would have emerged in the legislative process absent the registration obstacle. One criticism of a more interventionist interpretation of the Carolene Products doctrine is that any effort to reconstruct a "fair" political process and predict the outcomes it would have favored absent the obstructive legislation would be of staggering complexity. See Ackerman, Beyond Carolene Products, 98 Harv. L. Rev. $713,715,724-28,740$ (1985). Still, arguably, the process defects claim can be asserted beyond the procedural issue present in this case, such as to protect powerless minorities from hostile substantive legislation. See Cover, The Origins of Judicial Activism in the Protection of Minorities, 91 YALE L.J. 1287 (1982). Removing the registration requirement simply frees the qualified electorate to participate on election day, enabling the democratic process to function unimpeded. 
equal access, requiring only that the classification in question not discriminate among definable real life populations, interprets too narrowly the qualification and reapportionment cases. Many of the voter qualifications/ regulations found unconstitutional in the past were indeed facially discriminatory along such lines as wealth, ${ }^{30}$ race, ${ }^{31}$ occupation, ${ }^{32}$ property ownership, ${ }^{33}$ or geography. ${ }^{34}$ However, in these cases the Court has generally discussed both the right of equal access and a broader, more substantive, right to vote. ${ }^{35}$

The one-person, one-vote rule laid down in Reynolds v. Sims, ${ }^{36}$ a state reapportionment case, has both absolute and relative dimensions. While each qualified voter holds an entitlement to no more and no less than any other voter, she also has a positive entitlement to one vote per se. ${ }^{37}$

Voter qualification cases similarly address both relative and absolute rights. While the Court in Harper characterized the $\$ 1.50$ poll tax as a "classification" drawn along lines inconsistent with the equal protection clause, ${ }^{38}$ it found it unnecessary to identify the particular segment of the population harmed by the "classification." 39 The focus was on the base rights conferred on the entire potential electorate. By striking down the tax as applied to the entire electorate, not just the class of persons unable

30. See Harper v. Virginia Bd. of Elections, 383 U.S. 663 (1966) (poll tax prerequisite to voting violates equal protection).

31. See, e.g., Smith v. Allwright, 321 U.S. 649 (1944) (banning white primary laws); Guinn v. United States, 238 U.S. 347 (1915) (striking down grandfather clause that exempted descendants of people who voted prior to 1865 from literacy test voting prerequisite).

32. See Carrington v. Rash, 380 U.S. 89 (1965) (preventing resident military personnel from voting where stationed violates equal protection).

33. See Kramer v. Union Free School Dist. No. 15, 395 U.S. 621 (1969) (excluding non-property owners from school district election violates equal protection).

34. See, e.g., Reynolds v. Sims, 377 U.S. 533 (1964) (legislative reapportionment).

35. The few cases in which the Court has suggested that voting does not constitute a substantive right arose either in contexts not concerning the individual's right to vote, see City of Mobile v. Bolden, 446 U.S. 55, 77 (1980) (distinguishing individual's right to vote from group rights being adjudicated); San Antonio Indep. School Dist. v. Rodriguez, 411 U.S. 1, 35 n.78 (1973) (dicta), or pre-dating the emergence of the fundamental rights strand of equal protection analysis. See, e.g., Minor v. Happersett, 88 U.S. (21 Wall.) 162, 178 (1875); see supra note 17 and accompanying text distinguishing pre-Skinner cases.

36. 377 U.S. 533 (1964).

37. " $\Lambda$ s long as ours is a representative form of government, and our legislatures are those instruments of government elected directly by and directly representative of the people, the right to elect legislators in a free and unimpaired fashion is a bedrock of our political system." Id. at 562. "To the extent that a citizen's right to vote is debased, he is that much less a citizen." Id. at 567

For an interpretation of Reynolds as providing a substantive, not just a relative, right to vote, see Developments in the Law: Equal Protection, supra note 17, at 1181-83.

38. See Harper v. Virginia Bd. of Elections, 383 U.S. 663, 665 (1966) ("[O]nce the franchise is granted to the electorate, lines may not be drawn which are inconsistent with the Equal Protection Clause of the Fourteenth Amendment.").

39. Id. at 668-70 (Potential voter is burdened whether he "pays the fee or fails to pay it. . . [C]lassifications which might invade or restrain [fundamental rights] must be closely scrutinized and carefully confined. . . [T] he right to vote is too precious, too fundamental to be so burdened or conditioned."). 
to pay, the Court suggested that all persons had a base entitlement not to have their right to vote conditioned on payment of a poll tax. ${ }^{40}$

In Dunn, ${ }^{41}$ which overruled a durational residency requirement, the Court once again relied implicitly on both absolute and relative characterizations of the right to vote. The Court asserted the applicability of heightened scrutiny both when participation in elections "on an equal basis"42 is denied, and when exercise of the right to vote is "conditioned"43 or "restricted." 44 The latter characterization suggests a base entitlement of all qualified voters.

States do have the power under the Constitution to set voter qualifications, ${ }^{45}$ thereby defining the group of persons with this base entitlement to vote on election day. However, "in an election of general interest, [qualification] restrictions on the franchise other than residence, age, and citizenship" are subject to heightened scrutiny. ${ }^{\mathbf{4 6}}$

Candidate ballot access cases have relied on the right to vote as one justification ${ }^{47}$ for applying heightened scrutiny ${ }^{48}$ to ballot access restrictions. The right to vote relied on in candidate cases cannot be characterized as merely one of equal treatment since the precise voters who are harmed by a ballot access restriction cannot be pinpointed, ${ }^{49}$ and in fact no conceivable remedy in candidate cases has the impact of "equalizing" voter strength. Having another candidate on the ballot does shift the bal-

40. $I d$.

41. Dunn v. Blumstein, 405 U.S. 330 (1972).

42. Id. at 336 .

43. Id. at 337 (" $[\Lambda]$ more exacting test is required for any statute that "place[s] a condition on the exercise of the right to vote." " (quoting Bullock v. Carter, 405 U.S. 134, 143 (1972) (emphasis added))).

44. Id. at 336 (" " $[\mathrm{B}]$ efore that right [to vote] can be restricted, the purpose of the restriction and the assertedly overriding interests served by it must meet close constitutional scrutiny.' " (quoting Evans v. Cornman, 398 U.S. 419, 422 (1970) (emphasis added))).

45. See supra note 15. But see note 87 for position that registration is not properly classified as a "qualification."

46. Hill v. Stone, 421 U.S. 289, 297 (1975). The Court's wording in Hill was that such restrictions must promote a "compelling state interest." Finding the state's asserted interest not to be compelling, id. at 301, the Court did not need to reach the question of least restrictive means. Hill relied on Kramer v. Union Free School Dist. No. 15, 395 U.S. 621 (1969), which did require that such restrictions be narrowly tailored to fulfill the compelling interest. Id. at 626-27, 632 .

47. The right of political expression is the other justification. See, e.g., Anderson v. Celebrezze, 460 U.S. 780, 787 (1983); Illinois State Bd. of Elections v. Socialist Workers Party, 440 U.S. 173, 184 (1979); Storer v. Brown, 415 U.S. 724, 756 (1974) (Brennan, J., dissenting); Williams v. Rhodes, 393 U.S. 23,30 (1968).

48. See, e.g., Anderson, 460 U.S. at 789 (courts must determine extent to which state's interests make it necessary to burden individual's voting rights); Illinois State Bd. of Elections, 440 U.S. at 184 ("[ $\Lambda]$ state must establish that its classification is necessary to serve a compelling interest."); Lubin v. Panish, 415 U.S. 709, 716 (1974) (states must not adopt "unduly burden[some]" means to achieve ends).

49. See generally Anderson, 460 U.S. at $793 \mathrm{n} .15$ (equal protection analysis applicable even when persons harmed by classification cannot be precisely identified); Bullock v. Carter, 405 U.S. 134, 144 (1972) (indeterminate number of voters burdened by candidate restriction). 
ance, increasing the potential effectiveness of votes for the new candidate on the ballot, but it does not "equalize" effectiveness. Candidate cases thus do not even have the equal access component.

\section{B. Any Restriction on the Right To Vote Triggers Strict Scrutiny}

Gandidate ballot access cases and reapportionment cases, as discusssed above, address the scope of the right to cast an effective ballot. ${ }^{50}$ However, consideration of the effectiveness of the ballot would be meaningless unless the qualified voter is able to cast a ballot unencumbered in the first place. One must consider what level of infringement on this right is sufficient encumbrance to trigger strict scrutiny. The Supreme Court has not established one threshold of harm at which strict scrutiny is triggered for all fundamental rights. The "any restriction" standard applied in voting cases is thus decisive here. This standard is consistent with the nature of voting, an unconditional fundamental right.

\section{Fundamental Rights Generally}

In right to travel cases, for instance, strict scrutiny is applied when the right is "penalized." cases the Court has required varying degrees of burden according to the fundamental right at issue, before applying heightened scrutiny. The Supreme Court has never defined the parameters of these standards, ${ }^{54}$ nor suggested that their applicability extends beyond the particular fundamental right in question.

A key factor distinguishing the voter registration context from a fundamental right protected only from "unduly burdensome interference" is the

50. E.g., Reynolds v. Sims, 377 U.S. 533, 565-66 (1964):

Full and effective participation by all citizens in state government requires . . that each citizen have an equally effective voice in the election of members of his state legislature. Modern and viable state government needs, and the Constitution demands, no less. . . . [T] he achieving of fair and effective representation for all citizens is . . . the basic aim of legislative apportionment ....

51. Memorial Hosp. v. Maricopa County, 415 U.S. 250, 253, 256 (1974) (denial of free nonemergency medical care penalizes right to travel); Dunn v. Blumstein, 405 U.S. 330, 338, 340 (1972) (durational residency requirement for voting penalizes right to travel); Shapiro v. Thompson, 394 U.S. 618,634 (1968) (waiting period to receive welfare benefits is penalty on right to travel).

52. E.g., Bates v. City of Little Rock, 361 U.S. 516, 524 (1960); NAACP v. Alabama ex rel. Patterson, 357 U.S. 449, 560 (1958).

53. E.g., Zablocki v. Redhail, 434 U.S. 374, 385 (1978) (freedom from unjustified interference with marriage); Maher v. Roe, 432 U.S. 464, 474 (1977) (freedom from "unduly burdensome interference" with right to abortion); Carey v. Population Serv. Int'l, 431 U.S. 678, 686 (1977) (regulations regarding contraception cannot impose "burden").

54. See, e.g., Democratic Party of United States v. Wisconsin ex rel. La Follette, 450 U.S. 107, 123-24 (1980) (court accepted without analysis plaintiff's claim that infringement of associational rights was "substantial"); Memorial Hosp. v. Maricopa County, 415 U.S. at 257-58, 260 (court explicitly declined to define minimum amount of impact constituting "penalty"). 
nature of the state interest involved. Courts have at times appeared to anticipate the existence of state interests competing directly with the exercise of a fundamental right at the stage of determining the threshold at which strict scrutiny will be triggered. The higher threshold acts as an implicit balancing test in cases where exercise of the individual right and pursuit of the state interest are in direct contradiction, and thus avail themselves of no alternative, less restrictive means by which they could be concurrently pursued. The variant standard that results can be understood by comparing judicial treatment of the unconditional right to travel with the right to have an abortion free from "undue" interference. ${ }^{55}$ The right to an abortion is "conditional" because the state's potential interest in childbirth, under current medical technology, ${ }^{56}$ is inextricably intertwined with exercise of the right to an abortion. The two conflicting interests are implicitly balanced by requiring a higher threshold of interference with the right to an abortion than would be applicable to an "unconditional" right, before applying heightened scrutiny. In contrast, the state cannot have a valid interest in deterring a person from exercising the right to travel. ${ }^{57}$ Thus, it is not an "infringement" for the state to provide economic incentives to encourage the woman to opt for childbirth rather than to exercise her right to an abortion, while it would be an "infringement" for the state to provide economic incentives that distinguish between new arrivals and long time residents in the state, discouraging travel.

Voting is more aligned with free speech and travel as an unconditional right, requiring a lower threshold of injury before applying strict scrutiny. The state's only potentially valid compelling interest in support of the voter registration requirement, fraud prevention, ${ }^{58}$ aims to prevent unqualified votes from being counted, not to prevent qualified voters from voting. Every individual who meets the age, residency, citizenship and competency requirements, and who is blocked from voting by the registration requirement, has lost a fundamental right for the sake of a collateral matter, fraud prevention.

Finally, in determining the applicable standard, courts have drawn a

55. Maher v. Roe, 432 U.S. 464, 474 (1977) (woman's right to protection from "unduly burdensome interference with her freedom to decide whether to terminate her pregnancy... implies no limitation on the authority of a State to make a value judgment favoring childbirth over abortion, and to implement that judgment by the allocation of public funds").

56. In theory, the state's interest in childbirth need not conflict directly with the woman's right to an abortion. If medical technology reached the point where the woman could stop her pregnancy while not interfering with the development of the fetus outside her womb, then the two interests could be pursued concurrently. Since medical technology has not yet reached that point, the law has needed to reconcile the conflicting interests.

57. Shapiro v. Thompson, 394 U.S. 618, 643 (1968) ("Like the right of association . . [the right to travel] is a virtually unconditional personal right, guaranteed by the Constitution to us all.").

58. See infra notes $92-105$ and accompanying text. 
distinction between removing state-imposed obstacles and undertaking "affirmative" steps. State-imposed obstacles to fundamental rights are subject to strict scrutiny under the equal protection clause while the state's failure to extend a privilege, as an "affirmative" step, need only meet the rationality test. ${ }^{59}$ Arguably, as long as the infringement stems from state action, the obstacle would be subject to strict scrutiny even if some persons would be able, with effort, to surmount it. ${ }^{\text {o0 }}$ Since any form of pre-election day registration is a state-imposed barrier encumbering the right to vote, no level of "effort" a state exerts to ease the obstacle renders a registration requirement an affirmative aid to the right to vote. States that use mail registration, deputy registrars, satellite registration sites, and extended office hours merely make it easier to overcome the state-imposed registration requirement. In such cases, the state has done nothing affirmatively to induce the individual to exercise the right to vote.

\section{The Voting Context}

In reapportionment, voter qualification, and candidate ballot access cases, the Supreme Court has affirmed that "any restriction" on the right to vote triggers heightened scrutiny. The Court in Reynolds first established the "any restriction" standard. ${ }^{61}$ This standard was reasserted in

59. For examples of cases applying the rationality test to "affirmative" legislation, see Maher v. Roe, 432 U.S. 464 (1977) (financing abortions "affirmative," because right to abortion merely protects from "undue interference"); San Antonio Indep. School Dist. v. Rodriguez, 411 U.S. 1, 39 (1973) (efforts to extend education "affirmative" because education not fundamental right); McDonald v. Board of Election Comm'rs of Chicago, 394 U.S. 802 (1969) (allowing only certain sectors of electorate to use absentee ballots "affirmative" because no constitutional right to absentee ballot).

"Affirmative" legislation is often justified by the state's interest in taking legislative reform "one step at a time." See Minnesota v. Clover Leaf Creamery Co., 449 U.S. 456, 466-68 (1981) ("affirmative" legislation may be taken "one step at a time" for budgetary reasons); McDonald, 394 U.S. at 809 ("affirmative" action may proceed one step at a time according to which issue is "most acute to the legislative mind"). Since fiscal constraints are not a compelling interest, see infra note 110 and accompanying text, this rationale has not been applied and cannot be justified under strict scrutiny, when fundamental rights or "suspect classifications" are infringed. See Note, Reforming the One Step at a Time Justification in Equal Protection Cases, 90 YALE L.J. 1777 (1981).

60. The fact that by individual volition an obstacle can be surpassed does not necessarily lower the applicable standard and appropriate remedy. The Court has subjected state-imposed obstacles to strict scrutiny and imposed broad remedies even when persons affected were unwilling, though not necessarily unable, to overcome the obstacle. See Bullock v. Carter, 405 U.S. 134, 146-48 (1972) (although Court stressed candidate's alleged inability, not simply unwillingness to pay filing fee, remedy was to eliminate filing fee system for everyone); Harper v. Virginia State Bd. of Elections, 383 U.S. 663, 668 (1966) (Court abolished poll tax for all, not just for those unable to pay it). But see Lubin v. Panish, 415 U.S. 709, 714-19 (1974) (court drew unwilling/unable distinction at remedy stage, providing less restrictive alternative only for candidates unable to pay filing fee); Rosario v. Rockefeiler, 410 U.S. 752, 761-62 (1973) (rationality standard applied; petitioners admitted not changing parties earlier due to own inaction, not state action); McDonald v. Board of Election Comm'rs of Chicago, 394 U.S. 802,808 (1969) (rationality standard applied; no indication in record that appellant sought means of voting other than by absentee ballot).

61. "[S]ince the right to exercise the franchise in a free and unimpaired manner is preservative of other basic civil and political rights, any alleged infringement of the right of citizens to vote must be carefully and meticulously scrutinized." Reynolds v. Sims, 377 U.S. 533, 562 (1964) (emphasis 
Harper v. Virginia Board of Elections ${ }^{62}$ to overrule a $\$ 1.50$ poll tax voting prerequisite and subsequently reaffirmed in Bullock $v$. Carter, ${ }^{63}$ distinguishing the standard applicable in voter qualification and candidate ballot access cases.

Congressional reapportionment cases provide the best factual context for pinpointing the minimal level of injury sufficient to trigger strict scrutiny, because district sizes can be changed to conform to a virtually infinite scale of possibilities. ${ }^{64}$ Qualification cases provide a less instructive basis of comparison for ascertaining that threshold level of harm because of the individualized factual circumstances in which they arise. ${ }^{65}$ In candidate cases, the applicable standard is distinct because the right to vote arises only indirectly, and within the framework of the conditional "right" of ballot access. ${ }^{86}$ Thus, the level of injury there required to invoke strict scrutiny is not appropriate in the registration context. ${ }^{67}$

added).

62. 383 U.S. at 667-68.

63. 405 U.S. at 143.

64. See infra notes $68-70$ and accompanying text.

65. K.g., Hill v. Stone, 421 U.S. 289 (1975) (in dual box voting system, non-property owners burdened because not significantly less interested in and affected by bond referendum); Dunn v. Blumstein, 405 U.S. 330 (1972) (durational residency requirement not least restrictive means to foster compelling state interest); Harper v. Virginia Bd. of Elections, 383 U.S. 663 (1966) (\$1.50 poll tax sufficient burden to trigger heightened scrutiny); Carrington v. Rash, 380 U.S. 89 (1965) (disenfranchising military unconstitutional because not narrowly tailored to tap only bona fide residents for voting).

66. See infra notes $77-80$ and accompanying text.

67. In candidate cases, the harm measured is the degree to which voters might suffer by being unable to cast a ballot for the excluded candidate. See, e.g., $\Lambda$ nderson v. Celebrezze, 460 U.S. 780,786 (1983) " Our primary concern is with the tendency of ballot access restrictions "to limit the field of candidates from which voters might choose." " (quoting Bullock, 405 U.S. at 143)); Illinois Elections Bd. v. Socialist Workers Party, 440 U.S. 173, 184 (1979) ("By limiting the choices available to voters, the State impairs the voters' ability to express their political preferences."). While the right to vote is unconditional, the "right" to ballot access is conditioned by the state's valid interest in orderly elections. That is, the state has an interest in providing access only for candidates with some modicum of voter support and can provide a narrowly-tailored obstacle to ballot access as a means. The theory is that while giving a candidate ballot access may benefit her supporters, the confusion engendered by a crowded ballot may concurrently impose costs on other voters. In addition, the electoral process as a whole may be disrupted to the extent it becomes harder to pinpoint one candidate who is the choice of the majority. E.g., American Party v. White, 415 U.S. 767, 782 n.14 (1974) (state interest in avoiding undue voter confusion); Bullock, 405 U.S. at 145 (state interest in limiting the number of candidates on the ballot); see also Jenness v. Fortson, 403 U.S. 431, 442 (1971) (state interest in assuring candidate on ballot has modicum of voter support); Williams v. Rhodes, 393 U.S. 23, 32 (1968) (state interest in maintaining electoral system in which election winner likely to be choice of majority).

The nature of this state interest in ballot access cases suggests that the threshold of harm which the candidate's supporters must suffer in order to trigger strict scrutiny would logically be higher than that necessary to challenge registration, the abolition of which would impose no costs on other voters, in order to equalize the net injury incurred in both cases. The higher threshold of harm required before applying strict scrutiny in ballot access cases can be analogized to the higher threshold the Court has required regarding the conditional right to an abortion. See supra notes 55-57 and accompanying text. In both cases the state has an interest directly contrary to exercise of the individual "right," necessitating implicit balancing of the competing interests. Thus, while Bullock reaffirmed the holding in Harper that "ihe placing of even a minimal price on the exercise of the right to vote" was not permissible, Bullock, 405 U.S. at 142, consideration of the derivative and conditioning factors 
The standard applied in congressional reapportionment cases, that no population variation is permissible which could "practicably" be avoided, has required the equivalent of the "least restrictive means" of redistricting. In these cases, the Supreme Court has not tolerated even de minimis population variations among districts unless the state can demonstrate a legitimate objective. ${ }^{68}$ Karcher $v$. Daggett ${ }^{68}$ the Supreme Court's most recent congressional reapportionment case, involved a districting plan in which the average variation from perfectly equal districts was just $0.1384 \%,{ }^{70}$ less than the probable error in census figures. The Court held that the plan violated the one-person, one-vote rule. Plaintiffs met their burden of demonstrating that alternative districting plans with smaller population variations were available, while defendants failed to justify the variation as necessary to achieve a legitimate goal. ${ }^{71}$ Thus, a very minimal variation in population was sufficient injury to warrant requiring implementation of a less restrictive plan.

\section{Applying Fundamental Rights Analysis to Registration}

Registration is a classification that distinguishes between qualified persons who can and cannot cast a ballot on election day, according to whether they surmounted an obstacle, possibly weeks before the election. It is the state-imposed obstacle in the form of registration, not simply individual volition, that hinders exercise of the right. The registration require-

is necessary in ballot access cases. Id. at 143 ("Not every limitation or incidental burden on the exercise of voting rights is subject to a stringent standard of review.").

68. Karcher v. Daggett, 462 U.S. 725, 734 (1983) (no de minimis population variation in congressional districts permissible, which could practicably be avoided, absent state justification); Kirkpatrick v. Preisler, 394 U.S. 526, 530-31 (1969) (same). The Court has diverged from this strict standard in state reapportionment challenges. See Brown v. Thomson, 462 U.S. 835, 842-43 (1983) (ten percent population disparity needed in state districts to establish prima facie showing of violation, requiring justification by state); Mahan v. Howell, 410 U.S. 315, 321-23 (1973) (distinguishing "absolute equality" test used in congressional reapportionment from "substantial equality" standard applicable to state reapportionment). The court has not justified this differential in standard explicitly on considerations of constitutional federalism. See Note, The Constitutional Imperative of Proportional Representation, 94 Yal.F L.J. 163, 167 n.22 (1984). Thus, the distinction does not necessarily require differential treatment of registration for federal and state elections. Instead, in distinguishing the state reapportionment cases falling under the equal protection clause and congressional reapportionment cases falling under article I, section 2 of the Constitution, the Court has emphasized that certain state objectives may have increased importance in the context of state districting. See Brown v. Thomson, 462 U.S. at 842 (some deviation from population equality in state districting permissible to allow " 'maintain[ing] the integrity of various political subdivisions' and 'provid[ing] for compact districts of contiguous territory" ") (quoting Reynolds v. Sims, 377 U.S. 533, 578 (1964)).

69. 462 U.S. 725 (1983).

70. Id. at 728 .

71. Defendants failed to demonstrate a causal relationship between the one justification emphasized-preserving minority voting strength-and the population variance. Id. at 743. The Court did suggest, in dicta, that other state interests, if substantiated, could justify small population deviations. "Any number of consistently applied legislative policies might justify some variance, including, for instance, making districts compact, respecting municipal boundaries, preserving the cores of prior districts, and avoiding contests between incumbent Representatives." Id. at 740. 
ment infringes the individual's right to vote at least as much as does a districting plan that dilutes the individual's vote a fraction of one percent.

\section{A. Registration Constitutes "Any Restriction" on the Right To Vote}

\section{Logically, Pre-Election Day Registration Is Burdensome}

By definition, having a pre-election day registration requirement is more restrictive than leaving the right unencumbered. An unregistered, would-be voter who becomes aware of her interest in a given election only after the registration deadline has passed is blocked from exercising her right to cast a ballot on election day. Thus, any pre-election day registration requirement logically is a restriction on the right to vote and is therefore subject to strict scrutiny.

The level of scrutiny should not vary according to the permissiveness of a state's current registration practices because registration itself is a restriction sufficient to warrant strict scrutiny. Requiring a plaintiff to demonstrate that, in her particular fact situation, registration is a substantial hurdle, before applying strict scrutiny, would be inappropriate since this amounts to looking at the merits of the claim in order to set the standard of review. ${ }^{\mathbf{2}}$

The only court decision to address the question of the threshold at which strict scrutiny is triggered in the registration context, Coalition for Sensible and Humane Solutions $v$. Wamser, ${ }^{73}$ took this erroneous approach. The court in Coalition did not dispute that there is a substantive right to vote. ${ }^{74}$ However, it found the rationality test applicable upon first concluding that the plaintiff had sufficient opportunities to register. The Coalition court incorrectly relied upon McDonald v. Board of Election Commissioners" $^{\mathbf{7 5}}$ for the principle that the "standard of rationality, not compelling state interest, applies when voting procedures do not absolutely preclude individuals from voting." ${ }^{.76}$ Actually, the court in $\mathrm{McDonald}$ recognized the position taken in Harper that "because of the overriding importance of voting rights, classifications "which might invade or restrain them must be closely scrutinized and carefully confined." "77 Because the

72. The question whether sufficient registration opportunities exist is more appropriately addressed at the stage of evaluating whether the means used are the least restrictive. Depending on the degree to which the state is actually using registration as a means to prevent fraud, some state statutes might end up passing as the least restrictive means. See infra notes 113-26 and accompanying text.

73. 590 F. Supp. 217 (E.D. Mo. 1984), affd, 771 F.2d 395 (8th Cir. 1985).

74. Id. at 222 (presuming right to vote but requiring restriction be of some substance before compelling state interest test triggered).

75. 394 U.S. 802 (1969).

76. 590 F. Supp. at 222 .

77. 394 U.S. at 807 . An alternative reading of McDonald is that the court drew a distinction between the "right to vote" and the "right to vote conveniently," finding strict scrutiny applicable to the former but not the latter. The court in Coalition followed this interpretation of McDonald in 
plaintiffs in that case, pretrial detainees, apparently did not allege that the state restricted their right to vote (claiming instead a right of equal access to a particular form of voting, by absentee ballot), strict scrutiny was not mandated. The analysis developed here is fully consistent with $\mathrm{McD}$ onald in that plaintiffs would be directly challenging the restriction-registration-rather than insisting on the right to be registered in a specific manner.

\section{Statistical Studies}

Statistics substantiate the conclusion that registration constitutes "any restriction" on the right to vote. Voter participation rates in the United States declined significantly as states began to introduce personal registration requirements, toward the end of the nineteenth century. ${ }^{78}$ Moreover, the registration rates in the states with the least-restrictive registration procedures are significantly higher than the national average, while turn-

concluding that an infringement of the right to vote must be of some substance before strict scrutiny is triggered.

This Note argues that such an interpretation does not necessarily follow from the language in McDonald. McDonald did not confront directly the right to vote. Rather, the matter before the Court was the narrow question of whether there exists an entitlement to an absentee ballot. Justice Marshall, writing for the majority in Hill v. Stone, 421 U.S. $289,300 \mathrm{n} .9$ (1975), similarly made this interpretation of McDonald ("[T] he only issue before the Court [in McDonald] was whether pretrial detainees in Illinois jails were unconstitutionally denied absentee ballots . . . . [T] the record to indicate that the challenged Illinois statute had any impact on the appellants' exercise of their right to vote."). Under this interpretation, McDonald does not contradict the notion that strict scrutiny is applicable when the right to vote is restricted. This understanding of McDonald is also consistent with the long line of reapportionment cases, see infra note 68 and accomapnying text, candidate ballot access cases, see infra note 67 and accompanying text, and qualification cases, e.g., Harper v. Virginia Bd. of Elections, 383 U.S. 663 (1966) (all resident citizens of voting age eligible to vote upon payment of poll tax); Carrington v. Rash, 380 U.S. 89 (1965) (servicemen had the option of voting by absentee ballot in their home states), that make clear that the threshold for triggering strict scrutiny is far below absolute denial of the right to vote.

The absentee ballot issue presented in McDonald is distinct from voter registration also in that it directly implicates the manner of holding elections, a matter left to state legislatures and Congressional oversight under article I, section 4 of the Constitution. Pre-election day regulations, such as registration, are not explicitly left to legislative determination.

78. Burnham, The Appearance and Disappearance of the American Voter, in El.Ecroral. PaRTICIPAJion: $\Lambda$ Comparative ANal.ysis 48-49, 53-55 (R. Rose ed. 1980). In most other democracies, the government assumes the responsibility for initiating registration. See Stone, supra note 1, at 521. The United States remains the only Western democracy that does not have some form of compulsory or automatic registration. Id. at 521; D. Glass, P. Squire \& R. Wolfinger, What the United States Can Learn from Other Democracies $A$ bout Voter Turnout (unpublished, unnumbered, undated manuscript) (photo. reprint on file with author). Not surprisingly, current U.S. registration and turnout as a percentage of voting age population are lower than in all other democratic countries except Switzerland. Powell, Voting Turnout in Thirty Democracies: Partisan, Legal, and Socia-Economic Influences, in El.kcioral. PARTICIPATION: $\Lambda$ Comparative $\Lambda$ Nal.ysis, supra, at 6 (table 1); D. Glass, P. Squire \& R. Wolfinger, supra, at table 1. Notably, the turnout rate in the U.S. in the late 1800 's (just prior to the introduction of personal registration) is comparable to that of the current rate in these other countries. Burnham, supra, at 49. Significantly, current U.S. turnout as a percentage of registered voters is also comparable to that in these other countries. D. Glass, P. Squire \& R. Wolfinger, supra, at table 1. 
out as a percentage of registered voters in those states differs little from the national average. ${ }^{78}$ One study concluded that, if all states followed the registration practices of the most permissive states, turnout would increase by over nine percent. ${ }^{80}$ These statistics suggest that registration poses a very real barrier to the right to vote, and that if this barrier were removed, more eligible persons would actually exercise their right to cast a ballot on election day.

\section{Evolving Standards of Equal Protection}

The Supreme Court's interpretation of equal protection has changed through time. ${ }^{81}$ In the voting rights context, earlier court cases and federal legislation had to tackle voting prerequisites that posed more blatant barriers to electoral participation, such as poll taxes, ${ }^{82}$ literacy tests, ${ }^{83}$ grandfather clauses, ${ }^{84}$ and durational residency requirements. ${ }^{85}$ The time has come for our equal protection jurisprudence to recognize that the practice of registration, while more subtle than these other devices, nonetheless places a very real restriction on the fundamental right to vote.

\section{B. Possible State Interests in Registration}

Once the plaintiff has established that "any restriction" on the right to vote is present, thereby triggering strict scrutiny, the state must prove that the registration requirement is the least restrictive means of serving a compelling state interest. ${ }^{\mathbf{8 6}}$

79. D. Glass, P. Squire \& R. Wolfinger, supra note 78, at table 4 . Consequently, a higher percentage of the voting age population in the less restrictive states actually votes.

80. Powell, supra note 78, at 11; see also Burnham, supra note 78, at 57.

81. The Supreme Court's reversal, in Brown v. Board of Educ., 347 U.S. 483 (1954), of the longheld "separate but equal" doctrine is a prime example of the evolution of equal protection.

82. Harper v. Virginia Bd. of Elections, 383 U.S. 663 (1966).

83. Oregon v. Mitchell, 400 U.S. 112, 118 (1970) (upholding constitutionality of Voting Rights Act provision banning literacy test voting prerequisite); Katzenbach v. Morgan, 384 U.S. 641,658 (1966) (same). But see Lassiter v. Northampton County Bd. of Elections, 360 U.S. 45 (1959) (preVoting Rights $\Lambda \mathrm{ct}$ case upholding constitutionality of non-discriminatory literacy test). For a discussion of the limited precedential value of Lassiter, see infra note 89.

84. Guinn v. United States, 238 U.S. 347 (1915).

85. Dunn v. Blumstein, 405 U.S. 330 (1972).

86. Courts have actually applied various constructions of heightened scrutiny to voting rights. See Karcher v. Daggetl, 462 U.S. 725 (1983) (legislative districting plan with average population variation of merely $0.1384 \%$ too restrictive under standard permitting only "necessary means of achieving a legitimate state objective"); Illinois State Bd. of Elections v. Socialist Workers Party, 440 U.S. 173, 184-85 (1979) (classification must be "necessary to serve a compelling interest," and must employ "least drastic means" to achieve that end); Lubin v. Panish, 415 U.S. 709, 716 (1974) (as applied to indigent candidates, filing fee not least restrictive means to obtain ballot access); Bullock v. Carter, 405 U.S. 134, 145-46 (1972) (method of financing primaries that burdens candidates does not withstand "close scrutiny"); see also Memorial Hosp. v. Maricopa County, 415 U.S. 250, 268 (1974) (perjury law as example of less restrictive means than durational residency requirement to fulfill interest in fraud prevention); Price v. Cohen, 715 F.2d 87, 92 (3d Cir. 1983) (dictum) ("The state may ... restrict voting . . only if the limiting classification has been precisely tailored to serve a 
A state might assert either "qualification" or "regulatory" interests in registration. Qualification interests can be conceptualized as those which further, in their own right, the intelligent use of the ballot, ${ }^{87}$ while regulations concern maintenance of the integrity of the electoral process. ${ }^{88}$

\section{Registration Cannot Rationally Serve as a Voter Qualification}

No state interest in registration as a voter qualification would be permissible since registration has no rational relation to the intelligent use of the ballot. ${ }^{80}$ The fact that an individual registered at some point in time bears no relation to the likelihood that she will cast an informed, rational ballot on election day. Furthermore, the state's interest in qualification can extend only to promotion of the intelligent use of the ballot. Registration as a means of selecting out an electorate more generally dedicated to the political process, rather than just interested in a particular election, would not therefore pass even the rational basis test.

Moreover, registration cannot be narrowly tailored to tap a more interested, informed electorate. Even if this were a compelling state interest, ${ }^{90}$ the registration process, by its nature, is both over- and under-inclusive. Not only does registration block access to voting by citizens who become informed and interested after the registration deadline, it allows for inclusion of persons who simply found it more convenient to register or who registered years ago but are uninformed about this election. The election

compelling governmental interest."). But see Marston v. Lewis, 410 U.S. 679, 682 (1973) (registration closing datc fifty days prior to election, except for Presidential elections, permissible "under current conditions").

87. Doty, The Texas Voter Registration Law and the Due Process Clause, 7 Hous. L. Rev. 163, 192 (1969). Under this qualification/regulation division, the use of registration to verify that only persons meeting the requisite age, citizenship, competency and residency requirements vote is a regulatory interest. In this capacity, registration does not act to qualify voters further, but rather acts as a proxy for the qualifications that the individual possesses independently of the registration requirement. Consistent with this division, most state constitutions and case law do not classify registration as a voter qualification. See Note, Federal Voter Registration: A Proposal To Increase Voter Participation, 8 Col.um. J.L. \& Soc.. Prons. 225, 234-36 (1972) [hereinafter Federal Voter Registration].

88. Kusper v. Pontikes, 414 U.S. 51 (1973).

89. See Harper v. Virginia Bd. of Elections, 383 U.S. 663, 666 (1966) (poll tax not rationally related to intelligent use of ballot). Lassiter v. Northampton County Bd. of Elections, 360 U.S. 45 (1959) (upholding literacy test voting prerequisite), is not to the contrary because a literacy test, unlike a registration requirement, has "some relation to standards designed to promote intelligent use of the ballot." Id. at 51. Nonetheless, the rational basis standard applied in Lassiter is of questionable precedential value because it pre-dates the application of heightened scrutiny to individual voting rights starting with Reynolds v. Sims, 377 U.S. 533 (1964). See L. TRIBE, supra note 25, at 770 . But see Karcher v. Daggett, 462 U.S. 725, 740 (1983) (range of possible legitimate state interests should not be underestimated); id. at 753, 760 n.26 (Stevens, J., concurring) (other state interests may be more important than perfect numerical equality); id. at 779-80 (White, J., dissenting) (many possible valid state interests); $i d$. at 787-88 (Powell, J., dissenting) (other valid considerations exist).

90. The Supreme Court has found the objective of intelligent use of the franchise to be legitimate. See Katzenbach v. Morgan, 384 U.S. 641, 654 n.15 (1966). The Supreme Court has not yet ruled on whether in a general purpose election the specific objective of an interested electorate is compelling. See Kramer v. Union Free School Dist. No. 15, 395 U.S. 621, 632 (1969). 
outcome undoubtedly affects all citizens, and thus, until election day any citizen has the potential of becoming interested in the issues and candidates. ${ }^{91}$ Certainly the behavior of candidates and pollsters in the weeks prior to an election suggests that they do not believe that either the citizens' awareness of the issues or their preference for candidates is frozen once the registration deadline has passed. The information flow concerning issues and candidates peaks in the weeks and even days before the election, often after the registration deadline has passed.

\section{The Compelling State Interest in Preventing Voter Fraud}

Historically, the most common justification given for the registration requirement has been prevention of voter fraud. ${ }^{92}$ Plainly, fraud prevention is a compelling state interest. States do have an interest in assuring that only persons meeting the residency, age, competency and citizenship qualifications vote, and do so only once. However, the legitimacy of a state's assertion that registration serves to prevent voter fraud hinges on whether the state is actually using registration for that purpose. ${ }^{93}$ Theoretically, pre-election day registration provides the state with time to verify that each registrant actually has a residence at the address indicated and is claiming no more than one address as a voting base. There are two types of verification mechanisms that could systematically make use of the time interval between a registration cut-off date and election day. First, states could compare both interstate and intrastate records to verify that no individual with the same identification information has registered to vote at more than one location. For example, dual registration by students living away from their permanent residences, and farmers finding temporary employment in the city could be identified by comparing registration records among different jurisdictions. ${ }^{94}$ Second, by sending non-

91. See Phoenix v. Kolodziejski, 399 U.S. 204, 209 (1970) ("when all citizens are affected in important ways by a governmental decision[,]" it violates equal protection to exclude otherwise qualified citizens from the franchise); Evans v. Cornman, 398 U.S. 419, 422-26 (1970) (state cannot have valid interest in restricting access to franchise by persons less affected by state activites as long as they are somewhat affected); see also Oregon v. Mitchell, 400 U.S. 112, 270-71 (1970) (opinion of Brennan, White \& Marshall, JJ.) ("particular group may not be denied the right to vote merely because many, or even most, of its members could properly be excluded").

92. See Federal Voter Registration, supra note 87, at 237 (citing numerous state cases giving fraud prevention as justification for voter registration); Burnham, supra note 78 , at 43 (stated reason for emergence of registration laws was fraud prevention). See generally J. HaRRis, RegisTration OF VoTres in THK: UnrThD STATrs (1920).

93. Cf. Karcher v. Daggett, 462 U.S. 725, 742 n.12 (1983) (mere assertion of a number of interests in district population disparity insufficient state justification); see also note 71 and accompanying text.

94. Actually, what fraud does result through isolated instances of farmers and students casting ballots in two jurisdictions may have only an inconsequential, random effect on the election outcome anyway. The minor impact of isolated votes cast for diverse candidates contrasts with the greater threat posed by a systematic effort to inundate a jurisdiction with fraudulent votes for a particular 
forwardable postcards to all registrants, or checking registrant data against utility company and telephone records, authorities could identify, prior to election day, persons registering with fraudulent addresses.

In practice, states vary in the degree to which they implement preelection day fraud detection methods. No state routinely checks its registration records against those of other states. ${ }^{95}$ Only when a new registrant admits to having previously registered elsewhere is it common for notice to be sent to the previous jurisdiction, directing cancellation of her registration there ${ }^{98}$ Some states do keep central computerized files enabling them to identify individuals who provided the same name, birthdate, and social security number for more than one address within the state. ${ }^{97}$ However, since many states do not require identification upon registering, ${ }^{98}$ an individual intent upon committing fraud could easily circumvent this intrastate checking mechanism by supplying different names and birthdates for different alleged addresses.

By sending out non-forwardable postcards far enough in advance of the election such that undeliverable cards are returned to the Election Commission before election day, election officials could spot registrants providing false addresses. In practice, even among those states that do send out non-forwardable postcards, ${ }^{99}$ the status of the registrant whose postcard is returned varies. Some states simply allow the registrant to vote as usual despite the alert that the registrant's data may have been false. ${ }^{100}$ In other

candidate.

95. Telephone interview with Marlene Cohn, Election Service Specialist, League of Women Voters, Washington, D.C. (Dec. 10, 1986); telephone interview with Peggy Sims, Ass't Director of Information, Federal Election Commission (Dec. 8, 1986).

96. Telephone interview with Marlene Cohn, supra note 95. See, e.g., ConN. GEN. STAT. ANN. $\$ 9-32$ (West Supp. 1987) (mandating registrar to notify other jurisdiction only if registrant admits to prior registration there). This mechanism does little to check fraud, however, since a new truthful registrant who inadvertently remains on the registration list of her previous jurisdiction would be unlikely to attempt to vote there anyway. Meanwhile, a person intent on fraud could easily circumvent this checking mechanism by not admitting that she is already registered in another state.

97. States that keep centralized registration lists include Alaska, Delaware, Kentucky, South Carolina, Virginia, and Wyoming. Arthur Young \& Co., Statewide Registration Systems I, 10-11 (Dec, 1,1977 ) (unpublished study) (photo. reprint on file with author).

98. Only nine states require registrants to supply positive identification. Id. at app. B. Most states rely simply on oath and signature requirements before recording a registrant. See, e.g., KY. REv. STAT: ANN. \$116.065 (Supp. 1986).

99. Approximately nineteen states make use, in some manner, of a non-forwardable postcard system to verify registrant information. Arthur Young \& Co., supra note 97 , at app. B.

100. In Mississippi, for example, the elections statute makes no mention of non-forwardable postcards. See Miss. CoDF. $\Lambda$ NN. $\$ \S 23-5-32$ to 23-5-313 (Supp. 1986). Election notification cards are sent out, but not in a non-forwardable manner. Telephone interview with Nancy Sulser, Special Projects Officer, Public Lands and Elections Divison of the Office of the Mississippi Secretary of State (Dec. 4, 1986). Fraudulent registrants, therefore, will not be caught through the postcards sent out. The Kentucky election statute only mentions purging registrants based on the county board's own knowledge. KY. Rkv. STAT. ANN. \$116.125 (Supp. 1986). Although voter identification cards are sent out to registrants, there is no provision for investigating the validity of registrants with nondeliverable cards. Telephone interview with Margie Wade, Data Processing Supervisor, Kentucky 
states, the registrant whose non-forwardable card was returned must on election day sign an affidavit or take an oath swearing that she really does reside at the challenged address. Only upon completion of this additional procedure may the questioned individual cast a ballot. ${ }^{101}$ Finally, some states, in addition to administering an oath or affidavit, will isolate the challenged ballot, leaving its validity to be resolved by investigation following the election. ${ }^{\mathbf{1 0 2}}$ Only this last group of states is in fact effectively using pre-election day registration as a means of flagging registrants with possibly fraudulent addresses before the election.

The fact that many states do not use registration as a verification tool to the degree theoretically possible supports the thesis that these states do not perceive fraud through registration to be a major problem. Systematic election fraud is more likely to be conducted by election officials than by private individuals, ${ }^{103}$ and at the voting rather than registration stage. ${ }^{104}$ Registration restrictions thus are ineffective means of combatting the more prevalent forms of voter fraud.

\section{C. "Least Restrictive Means" Analysis}

\section{Judicial Authority}

Courts have the authority to make a judgment concerning leastrestrictive means in the registration context. ${ }^{105}$ In school desegregation, ${ }^{106}$ mental hospital, ${ }^{107}$ and prison ${ }^{108}$ cases, courts have directed states to com-

\section{State Board of Elections (Dec. 3, 1986).}

101. In New York, for example, a registrant whose postcard is returned must take an affirmative oath before casting a ballot. Telephone interview with Marsha Watson, Office Manager, New York Board of Elections (Dec. 5, 1986). In Illinois an individual whose voter identification card is returned, or whose right to vote is challenged on election day, must show additional identification and complete an affidavit. Depending on the jurisdiction, this procedure takes place either at the polling place or at the county courthouse before the ballot is accepted. Telephone interview with Yvonne Smith, Assistant to Executive Director, Illinois State Board of Elections (Dec. 5, 1986).

102. In California, for example, a voter whose notification card is returned can vote by provisional ballot. The ballot is then isolated, to be counted only after the county clerk has verified the voter's information.

103. See Hearings on S. 1199, S. 2445, S. 2457 \& S. 2574 Before the Senate Comm. on Post Office and Civil Service, 92d Cong., 1st Sess. 78 (1971) (testimony of Sen. Kennedy); Federal Voter Registration, supra note 87 , at 231 .

104. Id. at 196 (statement of Sen. McGee); Cal.. El.fe. Code $\$ 14253$ (West Supp. 1987). One study found that only three percent of 6233 election boards surveyed reported claims of fraud through registration over the period 1963 to 1974. Voter Registration By Mail: Hearing on S. 1177 Before the Senate Comm. on Post Office and Civil Service, 94th Cong., 1st Sess. 369 (1975) (ABA Special Committee on Election Reform, Report to the House of Delegates (1974)); id. at 639, 646 (statement of Young Lawyers Section, Bar Ass'n of Dist. of Columbia (citing Office of Federal Elections, Survey of Election Boards-Final Report 22-23)).

105. See supra notes 12,86 .

106. See, e.g., Milliken v. Bradley, 433 U.S. 267 (1977).

107. See, e.g., Wyatt v. Stickney, 344 F. Supp. 373, 344 F. Supp. 387 (M.D. Ala. 1972). These two cases were consolidated on the appellate level, affd in material respects sub nom. Wyatt $v$. Aderholt, 503 F.2d 1305 (5th Cir. 1974).

108. See, e.g., Hutto v. Finney, 437 U.S. 678 (1978). 
ply with broad, detailed remedial plans. In reapportionment cases, courts have invalidated legislative districts with population disparities. ${ }^{109}$ Similarly, a structural change may be needed with respect to voter registration in order to vindicate the individual rights implicated.

The Supreme Court has never ruled that limiting state expenditures could be a compelling interest to which a remedial order must conform. ${ }^{110}$ The decrees issued in the desegregation, mental hospital, and prison cases often had the effect of requiring states to reallocate funds and make large additional expenditures. ${ }^{111}$ Such decrees have never been reversed on appeal specifically on the ground that compliance required undue state expenditure. Moreover, in the voting context, courts have required remedies that could only be implemented by increasing state expenditures. ${ }^{112}$ Thus, courts can clearly issue decrees defining least restrictive means in the registration context, with the expectation that states will undertake the requisite effort and expense needed for compliance.

\section{Least Restrictive Means in the Registration Context}

The key question in least restrictive means analysis is whether there exist alternative procedures that could be followed on election day to accomplish the fraud prevention purpose for which a state is actually using pre-election day registration. If such procedures exist, a state could serve its compelling interest while removing the registration closing date burden

109. See Karcher v. Daggett, 462 U.S. 725, 778 (1983) (White, J., dissenting) (25\% to 35\% of current House district lines drawn by courts).

110. The Supreme Court has in fact drawn a distinction between the relevance of fiscal constraints under the rationality standard and the inapplicability of such concerns under strict scrutiny. Bullock v. Carter, 405 U.S. 134, 149 (1972), for example, acknowledged that budgetary concerns may be a legitimate state interest, but do not constitute "an element of necessity" to be taken into consideration when structuring a remedy of an infringement on the fundamental right to vote; see also Carrington v. Rash, 380 U.S. 89, 95-96 (1965) (unconstitutional to disenfranchise military because less restrictive, albeit more costly, method available to tap precisely those eligible to vote); Bishop v. Lomenzo, 350 F. Supp. 576, 587 (E.D.N.Y. 1972) (registration closing date case holding that solution lies in providing more registrars, not in registering fewer people, a remedy requiring state expenditure).

111. See, e.g., Milliken, 433 U.S. at 289 ("federal courts [are permitted] to enjoin state officials to conform their conduct to requirements of federal laws, notwithstanding a direct and substantial impact on the state treasury"); North Carolina State Bd. of Educ. v. Swann, 402 U.S. 43, 46 (1971) (equity assures that "all reasonable methods be available to formulate an effective remedy"); Davis v. Board of School Comm'rs of Mobile County, 402 U.S. 33, 37 (1971) (court's powers may be applied broadly "to achieve the greatest possible degree of [relief], taking into account the practicalities of the situation"); Swann v. Charlotte-Mecklenburg Bd. of Educ., 402 U.S. 1, 15 (1971) ("Once a right and a violation have been shown, the scope of a district court's equitable powers to remedy past wrongs is broad, for breadth and flexibility are inherent in equitable remedies."); Wyatt v Aderholt, 503 F.2d at 1318 (if state legislature fails to allocate funds, court may take affirmative steps to ensure proper funding); see also Fiss, The Supreme Court, 1978 Term-Foreword: The Forms of Justice, 93 Hakv. L. REv. 1, 46-50 (1979) (approving of broad remedial action by courts).

112. See cases cited supra note 110. 
on the individual voter. Election day registration would still permit states to undertake more verification measures than many currently do. Verification measures that could easily accompany election day registration include the following: First, the requirements to take an oath and sign one's signature carry both a psychological deterrent against falsity ${ }^{113}$ and a legal deterrent in the form of penalties for perjury. Election day registration does remove the opportunity for election officials to compare signatures signed at two different times. It is still possible, though, to derive the psychological gain from requiring two sequential oaths, one upon registering and the second upon actually voting. Second, all election day registrants could be required to provide positive identification, such as a driver's license or utility bills, indicating the address the voter is claiming. Registrants who provide identification lacking an address or indicating an out of district address could be put immediately into a "challenged" category, to be included in the ballot count only upon subsequent verification of residency. Third, existing registered voters in the precinct could vouch for new registrants. Fourth, the currently common practice of requiring a voter to cast a ballot at only one designated polling site eliminates the possibility that an individual could use the same residence identification to vote at different polling sites. Thus, the procedural requirement that, regardless of where one registers, one must report to a designated polling place in order actually to vote serves as a concurrent check across jursidictions for multiple voters. Fifth, registrants could be advised upon registering that stiff penalties for providing fraudulent information will be enforced. Sixth, the role of both partisan and nonpartisan poll watchers could be enhanced; these poll watchers could challenge voters who they in good faith believe are providing fraudulent information. ${ }^{114}$ Sealed, marked ballots of challenged voters could be put in a separate box to be counted in the election results only once the identification provided is verified. The above procedures indicate that many alternative truth-inducing devices relied on in the registration process can be employed equally as well on election day.

In practice, states can be broken down into three categories regarding the feasibility of converting to an election day registration mechanism capable of countering fraud to the same degree as their current, pre-election

113. The psychological deterrent effect from taking an oath derives from the solemn circumstances under which it is administered, and the length of the oath. For further discussion of the psychological deterrent posed by a signature requirement, see Comment, A Model Voter Registration System, NAT'L Civ. Rrv., March 1984, at 104, 108.

114. Many states already permit individuals to challenge the qualifications of voters at the polls. E.g., InAHO CoDK $\$ 34-431$ (1981) (any elector can challenge registrant); Mich. CoMP. Laws ANN. $\$ 168.512$ (West Supp. 1986) (same). 
day mechanisms. ${ }^{115}$ The first group includes states that make no use of the time interval between the close of registration and election day for verification. ${ }^{116}$ These states have not demonstrated a need for pre-election day registration to combat voter fraud.

The second category includes states that use the verification tool of cross checking registrant information within the state through centralized files. This task, however, could be accomplished equally well on election day. ${ }^{\mathbf{1 1 7}}$ For example, several states already have computer systems that allow for rapid cross checking of registrant information throughout the state. ${ }^{118}$ By simply expanding this type of system, information provided by election day registrants could be immediately cross checked against the state's files to confirm that no one with identicial identification is registered for another address in the state. This system of checking would be facilitated by requiring election day registrants to provide positive identification. Cost could be minimized if the computer terminals were installed only in specified locations at which the individual would obtain a certificate of registration that she would then carry on to her designated polling site. ${ }^{119}$

115. Of course, states could move among these categories. For example, a state that began using non-forwardable postcards for fraud detection would move to category three, while a state that stopped using registration for any pre-election day fraud prevention purpose would move to category one.

116. See, e.g., Conn. GrN. S1'Ar. $\Lambda \mathrm{NN}$. $\$ \S 9-32,33$ (West Supp.1987) (only systematic fraud prevention mechanism mentioned is door-to-door registration data verification, a method that could be extended to affirmative voter registration); telephone interviews with $\Lambda$ lthea Tyson, Democratic Deputy Registrar, State of Connecticut and Judy Kozak, Director, League of Women Voters, State of Connecticut (Dec. 5, 1986); IDAHO CoDs $\$ \S 34-401$ to 34-438 (1981 \& Supp. 1986) (no provision for verifying registrant data prior to election day); telephone interview with Penny Ysrura, $\Lambda$ dministrative Secretary, Elections Division, Idaho Department of State ( $\Lambda$ pril 22, 1987); VA. CoDE $\Lambda$ NN. $\S$ 24.1-46 (12), (13) (1985) (non-forwardable postcards not used; registrar only obliged to strike from registration list persons known to registrar to be unqualified); telephone conversation with Deborah Boyde, Director of Computer Systems, Virgina Board of Elections, (Dec. 4, 1986); see also supra note 100 .

117. Should these computer runs require more than instantaneous processing time, the registration deadline could be set just far enough in advance of the election to allow for processing time, such as 48 hours prior to election day.

118. In Kentucky, for example, local registrars input voter registration data directly into a statewide computer system. Telephone interview with Jim Conner, Data Processing Manager, Kentucky State Board of Elections (June 1, 1987). In South Carolina, approximately 15 out of 46 jurisdictions can input directly into the state-wide computer system. Telephone interview with Jim Hendrix, $\Lambda$ ssistant Director, South Carolina State Election Commission (June 1, 1987). In California, registration infromation is centrally computerized. By statute, a county registrar may request the Secretary of State to check the county's registration list against those of other counties, CAL.. ELEC. CODE $\S 613$ (West Supp. 1987), and in practice, all county registration lists are run against each other at least once a year to detect duplicate registrants. Telephone interview with John Mott-Smith, Elections Analyst, California Board of Elections (June 2, 1987). In Illinois, 101 of 111 election jurisdictions have some election information computerized on a local level, and at least two jurisdictions, Chicago and Cook County, run registration lists against each other to spot duplicate registrants. Telephone interview with Yvonne Smith, supra note 101.

119. In Wisconsin, for example, persons who register on election day must first properly execute a registration form at the municipal clerk's office before proceeding to cast a ballot at the polling place. Wis. STAT. $\Lambda$ NN. $\$ \S 6.29,6.55$ (West 1986). This is a greater burden than allowing registra- 
The third set of states, those using non-forwardable postcards to identify false addresses, are using registration as a fraud detection device that cannot be duplicated by an election day mechanism. ${ }^{120}$ These states still must pursue that interest in the manner least restrictive of the right to vote. The National Municipal League has proposed door-to-door canvassing as a mechanism by which, at little additional expense, states could continue to use registration for verification while minimizing the burden on individuals posed by registration. ${ }^{121}$ Practices currently used in states more accommodating to registrants also suggest less restrictive means. For example, in Pennsylvania, registration forms are made available to those who apply for a driver's license, a library card, or admission to an institution of higher education. ${ }^{\mathbf{1 2 2}}$ Rhode Island provides for annual registration drives at each high school. ${ }^{123}$ California has used a toll-free telephone number for registration. ${ }^{124}$ Several states have recently established policies by which registration forms could be distributed through public agencies. ${ }^{126}$ Utility companies could regularly include a registration form with

tion at the polling place. Still, it does eliminate the time obstacle posed by pre-election registration closing dates.

120. Non-forwardable postcards sent out after the election as a check on election day registrants can also serve as a deterrent, if individual prosecutions follow the discovery of fraudulent information. Minnesota conducts such a post-election check. In Minnesota, the county auditor sends out nonforwardable postcards to all election day registrants after the election with the threat that illegal registrants will be investigated by the county attorney and prosecuted. MiNN. STAT. ANN. $\S \S$ 201.121(3), 201.275 (West Supp. 1987).

121. For a detailed description of the National Municipal League's voter registration proposal, see Comment, supra note 114. Under this mechanism, during a set time period each year, such as during the month ending thirty days before a primary or general election, canvassers would go doorto-door to collect names of eligible voters in the jurisdiction. Canvassers could either accept the word under oath of persons actually at the residence during the visit, concerning other eligible voters living at the residence, or could leave cards for the absent residents to fill out and return by mail, enabling a signature check for all household registrants. $\Lambda$ fter concluding the canvass, states would still have time to send out non-forwardable postcards to verify the results.

Door-to-door canvassing is already a familiar concept in the United States. Approximately onethird of the states have statutes permitting door-to-door canvassing as an alternative method of verifying aleady submitted registrant data. See, e.g., KY. Rrv. STAT. ANN. \$116.045(2) (Michie/BobbsMerrill 1982); Mı:H. Comp. Laws $\Lambda$ NN. $\$ 168.515$ (West 1967). Some state statutes list door-todoor canvassing as an optional method of recording new registrants. E.g. N.J. SrAT. ANN. $§ 19: 31-2$ (West Supp. 1986); UTAH CODE $\Lambda$ NN. $\$ 20-2-7.1(4)$ (1984). In at least one state, Idaho, some county registrars have directed door-to-door registration although the state statute does not explicitly mention it. Telephone interview with Penny Ysursa, supra note 117. One county in Idaho has achieved close to a $100 \%$ registration level by using door-to-door canvassing. See NATIONAI. CENTER

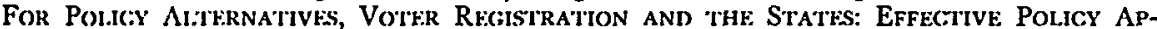
PROACHFS TO INC:REASING; PARTICIPATION 71 (1986) [hereinafter Voter Rrgistration].

122. PA. STA't. ANN. tit. 25, \$\$ 623-19.1(b), 951-17.1(b)(1) (Perdon Supp. 1986). At least six other states-Maine, Ohio, Michigan, Arizona, Oregon, and Colorado-permit registration at motor vehicle bureaus as well. Michigan in fact has shown an estimated $15 \%$ increase in registration level since 1970 when this reform was introduced. See Human Srrve Fund, Exrcutive Orders: A New Sirkatec; To Usf. Publit: Agincies To Incerease Voter Registration 4 (1985).

123. R.I. GrN. Laws § 17-9-4.1 (1981); see also Trx. El.r.: Conf ANN. \$ 13.046 (Vernon 1986) (registration forms distributed at high schools).

124. See Votrik Rroistration, supra note 121.

125. F.g., Wash. Rkv. Cobs $\Lambda$ NN. $\$ 29.07 .025$ (West 1987); Ohio Exec. Order No. 84-33 
materials sent to new customers signing up for utility service. These distribution schemes might be implemented either by deputizing some workers at the participating institutions or by permitting individuals to return the forms by mail. The cost of these mechanisms would be little more than the time required to train some employees to answer registrants' questions.

A state would not be relieved of its obligation to extend registration opportunites simply by demonstrating the use of some facilitative practices. It would be for courts to determine, case by case, the threshold at which anticipated fraud from a specific facilitative mechansim would justify the state in not implementing that particular mechanism. ${ }^{128}$ While increasing registration opportunites does not eliminate the barrier completely, it may present the least restrictive means in states actually using pre-election day registration for fraud prevention.

\section{ConClusion}

The constitutionality of the voter registration requirement should be challenged under the fundamental rights strand of equal protection analysis. Because registration itself is a restriction on the fundamental right to vote, strict scrutiny should be applied to any registration requirement. Of the various interests a state might assert, only the regulatory interest in fraud prevention could be both compelling and potentially appropriately addressed through registration. No form of pre-election day registration is necessary when states are not making use of registration as a means to combat voter fraud or if an alternative election day mechanism is available to accomplish the fraud prevention purpose for which the state is actually using its registration data. At a minimum, strict scrutiny requires states that are using the time interval between a registration deadline and the election to detect voter fraud to open up channels for registration, making it more likely that all qualified voters will be able to surmount the registration barrier.

(1984), New York Exec. Order No. 43 (1984), reprinted in Human Serve Fund, supra note 123, at 9, 13; see also Clark v. Cuomo, 66 N.Y.2d, 486 N.E.2d 794, 495 N.Y.S.2d 936 (1985) (upholding state executive order providing for voter registration in state service offices).

126. A state that could demonstrate a larger fraud problem might for example need to implement costly safeguards, such as supervisors of volunteer registrars, as it opens up registration opportunities. Thus, a state with a more severe demonstrated fraud problem might have higher costs related to implementation of facilitative registration practices than states that could not justify the need for such safeguards. 